\title{
APPLICATION OF INSECTICIDES CLOSE TO CROP HARVEST
}

\author{
B. G. MILls \\ Shell Oil New Zealand Ltd., Hamilton
}

Summary

The evaluation of two consumer-safe insecticides for the control of various insect pests in New Zealand, particularly for application to crops where residues of insecticides remaining may cause concern, is discussed. The materials, mevinphos and dichlorvos have been recently introduced in the U.S.A. and in Europe and have proved effective in controlling a wide range of insects. Their most important feature is that both are quickly broken down into harmless products and are, therefore, regarded as consumer-safe insecticides. The safety aspect applies to both stock and human consumers of plants sprayed with the insecticides. The tests carried out were not directly compared with the long-term residual type insecticides previously in common use, but were planned to observe how efficient these insecticides could be, particularly at close to harvest (or consumption) of various plants. Dichlorvos and mevinphos both show considerable promise to control efficiently many pests, together with safety to the consumer.

\section{INTRODUCTION}

THE DANGER of toxic residues remaining on crops from insecticides applied to them is now well known and is causing increasing concern. The object of the tests carried out with the two new substituted vinyl phosphates - dichlorvos and mevinphos - has been to observe the efficiency of the materials in controlling various insect pests under New Zealand conditions. As wide a range of pests as possible were treated but many more require to be investigated.

Dichlorvos and mevinphos, although recently introduced to many countries, have been thoroughly tested overseas on a wide range of insects (Harcourt \& Cass, 1957; Stern \& van den Bosch, 1957. Wolfenbarger \& Hibbs, 1958; Butcher \& Haynes, 1958; Haynes, et al., 1958; MacCuaig \& Yeates, 1960; Chaboussou \& Carles, 1960; Dormal, $1960)$; detailed studies have been made of the chemicals and the important aspect of residues remaining in plants and animals (Casida, et al., 1956, 1958; Richardson, 1958; Winfield, 1960). The safety of the use of mevinphos has been demonstrated many times by chemical and biological tests overseas and has been accepted by many authorities.

The general problem of toxic residues on crops and plants is normally associated with applications of insecticides to crops close to crop utilization. It is in this field that both mevinphos and dichlorvos can play an important role and results of applications of these materials have shown satisfactory control periods during early stages of crop establishment.

In France, mevinphos is the only systemic insecticide which may be used on market garden crops (Winfield, 1960); regulations covering the use of mevinphos and dichlorvos vary in different countries, the main feature being that, depending on rates used, and crops sprayed, the interval between application and consumption varies from 24 hours to 7 days, which is a very short time to permit control of pests at full crop maturity with complete safety to the consumer. 


\section{CHEMICAL CHARACTERISTICS OF DICHLORVOS MEvinpHos AND MEVINPHOS}

Mevinphos is available as an emulsifiable concentrate containing $2.4 \mathrm{lb}$ a.i. per gal. The formulation is completely miscible with oils and forms a spontaneous emulsion with water. The material is a deadly poison and handling instructions must be carefully observed.

In an aqueous solution mevinphos is subject to hydrolysis and cannot be stored in this form. Mevinphos is an organo-phosphorus insecticide which acts by:

(1) Systemic transmission within the plant,

(2) Contact action, and

(3) Fumigant effect.

Chemically mevinphos is a 3:2 mixture of cis- and trans-isomers of 2-methoxycarbonyl-1-methylvinyl dimethyl phosphate, which have the following structural formulae:

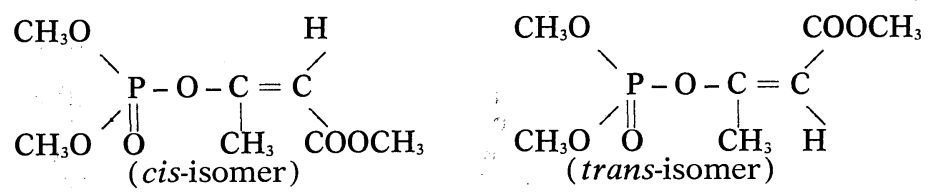

Hydrolysis proceeds faster under alkaline conditions and within the plant is rapidly reduced to non-toxic products by enzyme action (Winfield, 1960).

The high volatility (vapour pressure $=0.0029 \mathrm{~mm} \mathrm{Hg}$ at $21^{\circ} \mathrm{C}$ ) and quick absorption ensure that it does not remain on plant surfaces. The mammalian toxicity of technical material is high - acute oral L.D.50 (male rats) $5.0 \mathrm{mg} / \mathrm{kg}$.

DichloRvos

Dichlorvos is available as an emulsifiable concentrate containing $4.8 \mathrm{lb}$ a.i. per gal. Work on formulations of dusts, baits, granules and solutions is proceeding. Two per cent. active ingredient granules are under test in New Zealand.

Dichlorvos is $100 \%$ insecticidally active, and contains not less than $93 \%$ of the compound 2,2-dichlorovinyl dimethyl phosphate and not more than $7 \%$ of other insecticidally active related compounds.

It is a general poison being effective by:

(1) Contact action,

(2) Ingestion, and

(3) Inhalation or fumigant action.

Its effectiveness as a fumigant is outstanding. Dichlorvos has the structural formula:<smiles>COP(=O)(OC)OC(Cl)Cl</smiles>

Dichlorvos is stable in storage but is subject to decomposition when held at long periods at high temperatures, and in the presence of acids and alkalis, metallic iron, copper and brass, it will decompose in several days. 
It is less toxic than most other organo-phosphorus insecticides, but is poisonous to man and animals and strict observance of the health and safety measures is necessary.

It decomposes slowly when subjected to hydrolysis.

The high volatility (vapour pressure $=0.01 \mathrm{~mm} \mathrm{Hg}$ at $30^{\circ} \mathrm{C}$ ) and moderate mammalian toxicity (for $100 \%$ dischlorvos acute oral L.D.50 (rats) $50-80 \mathrm{mg} / \mathrm{kg}$ ), together with rapid decomposition places dichlorvos in the consumer-safe category with insignificant residues remaining on plants after application.

\section{IMPORTANT FEATURES OF DICHLORVOS AND MEVINPHOS FROM TRIALS}

(1) Toxicity to a wide variety of insects.

(2) Very rapid toxic action to insects.

(3) High volatility increasing speed and efficiency of kills.

(4) Low volume applications superior to high volume rates.

(5) Droplet size of spray dilutions - small size droplets increase efficiency.

(6) Length of time of effective insect control after applications although both materials have little residual action, the reinfestation periods were longer than anticipated.

(7) Time of applications - by close study of the insects, increased efficiency can be obtained when using these materials by considering at the time of application:

(a) Habits of the insects

(b) Soil and air temperatures, and

(c) Location of the insects on the plants or ground.

TRIALS

In all trials, the emulsifiable concentrates were used. The quantities quoted below are in terms of active ingredient per acre.

CRICKETS (Acheta commodus)

Mevinphos and dichlorvos were applied at various rates in trials in the Hauraki Plains and North Auckland areas. In these tests, mevinphos proved to be relatively inefficient against crickets at the rates used, but dichlorvos was most efficient in all tests carried out. In most cases, both spot trials (using 1/10th acre plots) and field tests were carried out with various rates of water per acre.

Spot Trials - North Auckland

\section{Mevinphos Trials}

The treatments and results are given in Table 1.

TABLE 1: MEVINPHOS SPOT TRIALS, NORTH AUCKLAND

\begin{tabular}{ccc}
\hline Mevinphos Rates $(o z)$ & Results recorded $181 / 2$ hr after Applications \\
\hline 1.2 & $\begin{array}{l}\text { No dead crickets, numerous live adults and } \\
\text { nymphs. }\end{array}$ \\
2.4 & $\begin{array}{l}\text { One dead adult on surface, sluggish adults and live } \\
\text { nymphs. }\end{array}$ \\
4.8 & Two dead adults on surface and sluggish adults.
\end{tabular}

In this trial, mevinphos was applied in 25 gal water per acre during fine weather in the afternoon to pasture which was $85 \%$ dry and $15 \%$ green grass; 30 crickets were counted from a 12 in. long crack in the ground.

No improvement was evident 45 hours after. All plots showed little promise for satisfactory control.

Spot Trial - Hauraki Plains

Treatments: Mevinphos at 2.4 and $4.8 \mathrm{oz}$ in $25 \mathrm{gal}$ water per acre. Incidence of crickets -80 to 100 per sq. yd. Pasture - 90\% dry, $10 \%$ green clover and weeds. 
Results: Only the $4.8 \mathrm{oz}$ plots gave any result with four to six dead crickets per square yard, 16 hours after application.

Field Tests

Field Test: Pasture 90\% dry and chewed, 10\% green clover and weeds. Conventional tractor-mounted spray equipment with centre point delivery jets. Mevinphos applied at $4.8 \mathrm{oz}$ in 25 gal per acre, over 3 acres, at 10 a.m.

Result: Less than $10 \%$ control observed 24 hours after application. Twenty per cent. control was obtained by applying the same rate over 2 acres on the same type of pasture at 9 p.m., but the result was also unsatisfactory. Results have been more promising by spraying in the evening when the crickets were more active on the surface.

Equipment: A complete contractor's spraying outfit with $18 \mathrm{ft}$ foom fitted with $32 \mathrm{~F}$ nozzles.

Application rates: Mevinphos at 2.4 and $4.8 \mathrm{oz}$ in 10 gal of water over 2 acres for each rate.

Conditions: Warm sunny day. Applied at 11 a.m. when numerous crickets active on the surface. There were 50 to 80 crickets per square yard. Soil cracked, $80 \%$ pasture very short, severely chewed out by crickets, $20 \%$ green clover and weeds.

Results: After two hours, 16 to 20 dead crickets per square yard were observed at the higher rate and this result did not alter after 24 hours. These crickets moved up to $30 \mathrm{ft}$ away from the spot where they received the spray. Although promising this was not satisfactory, as the $4.8 \mathrm{oz}$ rate achieved less than $50 \%$ control.

Spot Tests with Baits

Rates of mevinphos used : 2.4 and $4.8 \mathrm{oz}$ prepared as a bait, mixed with $25 \mathrm{lb}$ of bran, $4 \mathrm{lb}$ of molasses and $2 \mathrm{gal}$ of warm water. Baits applied at 3 p.m., 5 p.m. and 7 p.m. Results were promising with no significant difference between the times of application. Less than $50 \%$ control was achieved.

Discussion OF RESULTS

The features from the trials, which may be of use for future work are:

(1) The kills of crickets, under the conditions when tests were made, were mainly as a result of direct contact or the fumigant action, as very little live grass was present to allow for the systemic action to be of value. Early applications, before severe damage has occurred to the pasture, may improve results.

(2) Higher rates than $4.8 \mathrm{oz}$ may be required to give satisfactory control.

(3) Applications during the evening have proved to give the best results.

(4) Temperatures affect the presence of crickets on the surface. During warm conditions they are active on the surface either by day or night, but during cool temperatures they tend to remain down soil cracks.

(5) Lower volumes of water than $10 \mathrm{gal}$ per acre should improve the contact and fumigant action.

(6) Using kerosine or light oils in place of water as a carrier as used by MacCuaig and Yeates (1960) may improve results.

(7) Crickets were noted to be killed from eating those previously killed in plots treated.

Dichlorvos Trials

These tests were carried out in conjunction with mevinphos and the same conditions apply as for those listed above. 
Spot Triais

Applied under conditions as listed under the Hauraki Plains trials for mevinphos. Three areas were tested on $1 / 10$ th acre plots in $10 \mathrm{gal}$ water per acre. Results from the three series of plots are given in Table 2 .

TABLE 2: DICHLORVOS SPOT TRIALS, HAURAKI PLAINS

\begin{tabular}{cccccccc} 
Dichlorvos & 5 & Percentage Control & After & Application* & \\
(oz) & 10 & 30 & 2 & 8 & 24 \\
\hline 2.4 & min & min & min & hr & hr & hr \\
4.8 & 2 & 2 & 20 & 25 & 40 & 55 \\
9.6 & 5 & 15 & 40 & 75 & 90 & $90-100$ \\
& 8 & 20 & 55 & 80 & $95-100$ & $95-100$ \\
\hline
\end{tabular}

* Percentages are approximate, as they are based on counts of dead crickets from plots compared with original live counts. Late counts are confusing as numerous dead crickets are eaten by then. Counts include nymphs and adults.

All plots were most impressive with the $4.8 \mathrm{oz}$ rate giving very good control.

\section{Field Tests}

Conditions as for the first mevinphos field tests: One-acre areas were treated at 2.4, 4.8 and $9.6 \mathrm{oz}$ in 25 gal of water, with a contractor's spray outfit fitted with centre point delivery jets. Results were most promising and were similar to but somewhat less effective than the spot trials which were applied with hand equipment. Applied at 3.00 p.m. during fine, sunny weather. The same day at 8.00 p.m., the same equipment was used with $4.8 \mathrm{oz}$ in $25 \mathrm{gal}$ of water applied over 2 acres. The result was outstanding, a quick control being achieved as follows:

$$
\begin{aligned}
& 50 \% \text { control in } 30 \text { minutes, } \\
& 70 \% \text { control in } 31 / 2 \text { hours, and } \\
& 95 \text { to } 100 \% \text { control when inspected after } 13 \text { hours. }
\end{aligned}
$$

Results from another field test with the same equipment and conditions as listed under the second mevinphos field test, applying

\begin{tabular}{|c|c|c|c|c|c|}
\hline \multirow[b]{2}{*}{$\begin{array}{c}\text { Dichlorvos } \\
(\text { oz })\end{array}$} & \multicolumn{5}{|c|}{ Percentage Control After Application } \\
\hline & $\begin{array}{c}5 \\
\text { min }\end{array}$ & $\stackrel{8}{\min }$ & 25 & hr & $\begin{array}{c}5 \\
h r\end{array}$ \\
\hline $\begin{array}{l}2.4 \\
3.2 \\
4.8\end{array}$ & $\begin{array}{l}2 \\
4 \\
5\end{array}$ & $\begin{array}{r}3 \\
10 \\
12\end{array}$ & $\begin{array}{l}25 \\
60 \\
65\end{array}$ & $\begin{array}{l}30 \\
85 \\
80\end{array}$ & $\begin{array}{c}55 \\
90-100 \\
90-100\end{array}$ \\
\hline
\end{tabular}
10 gal of water per acre to 1-acre plots, are given in Table 3.

TABLE 3: DICHLORVOS FIELD TESTS, HAURAKI PLAINS

\section{Tests with Baits}

Applied under the same conditions as for the mevinphos bait tests. Rates of application were 2.4 and $4.8 \mathrm{oz}$ prepared as a bait with $25 \mathrm{lb}$ of bran, $4 \mathrm{lb}$ molasses and 2 gal warm water. Results were almost identical with those listed for the spot trials for dichlorvos.

Spot Test Granules

A spot trial using 1/10th-acre plots applying 2\% dichlorvos granules was carried out with very little result. Rates used were $2.4,4.8$ and $7.2 \mathrm{oz}$. The reason for this is not known and further tests are to be carried out.

\section{Discussion of Results}

Dichlorvos has given outstanding results for cricket control under these trials. Features of the results are:

(1) Very rapid kills of crickets - some within five minutes after application. 
(2) Dead crickets remain on the surface, or affected ones come to the surface as fumes penetrate soil cracks.

(3) Rates between 3.2 and $4.8 \mathrm{oz}$ are sufficient to give good control of crickets.

(4) Low rates of water per acre and small droplet size improve results. Apparently the fumigant action is increased under these conditions.

(5) Re-infestation of crickets was not a problem in the tests, even four weeks after application.

\section{TESTS ON OTHER INSECT PESTS}

White Butterfly Caterpillars (Pieris rapae)

Applications of mevinphos at 2.4 and $4.8 \mathrm{oz}$ in rates of water varying from 6 to 40 gal, have been applied to various crops (cabbage, cauliflower, swedes, choumoellier, turnips and brussels sprouts). Tests included spot trials of $1 / 10$ th-acre size and field tests with farmers' and contractors' spray equipment.

Speed of kill was outstanding. Up to six hours was required for efficient control.

Lower water volumes improved results by as much as $50 \%$. The apparent reason for this on crops is that all the available chemical is rapidly utilized by young parts of the plants in the systemic action. Results show that $4.8 \mathrm{oz}$ are necessary for control with low water volumes. Short crops require 6 to $10 \mathrm{gal}$ and high crops require up to 25 gal per acre.

Applications of dichlorvos at 4.8 and $9.6 \mathrm{oz}$ gave similar results to mevinphos with $4.8 \mathrm{oz}$, giving excellent rseults.

APHIDS - Various Species

Various rates of dichlorvos and mevinphos were applied to aphids (Brevicoryne brassicae) on the following crops - cabbages cauliflowers, brussels sprouts, roses, citrus, turnips, swedes, and choumoellier. Rates of application were the same as for white butterfly. Both chemicals show outstanding qualities for aphid control with very rapid and complete kills and with periods of between ten and thirty days elapsing between applications and re-infestation. Aphids were killed on direct contact, with the systemic and fumigant action playing a vital role.

Aerial applications on crops of turnips, swedes and choumoellier, with mevinphos at $4.8 \mathrm{oz}$ in 6 gal of water gave outstanding results.'

ARMY WORM (Persectania aversa)

SPRINGTAILS (Collembola - numerous species)

FlIES - Various species, including the common house fly, field flies biting flies.

Mealy Bug (Pseudococcus spp.)

LOOPER CATERPILlars (Plusia chalcites)

Two-SPOTTED MITE (Tetranychus bimaculatus)

Trials on the above insects have proved that satisfactory control can be achieved with mevinphos $4.8 \mathrm{oz}$. Dichlorvos proved to be very efficient to control a variety of flies, springtails and army worm at $4.8 \mathrm{oz}$ in 10 to $20 \mathrm{gal}$ of water.

\section{GENERAL}

Further work is required to investigate these chemicals for control of numerous other important insect pests in New Zealand. Both materials have shown limitations in controlling some insects but they do show considerable promise in controlling numerous serious pests. Tests carried out were made by spot tests, followed by field trials. 
Confirming overseas reports, dichlorvos has shown exceptional qualities for the control of various species of flies. Tests with preparations of sugar baits containing $0.1 \%$ dichlorvos and spray rates of $4.8 \mathrm{oz}$ in $10 \mathrm{gal}$ water applied to poultry houses, pasture, and around fly-infested localities, proved efficient. The rapid contact and fumigant actions are outstanding.

\section{DISCUSSION AND SUMMARY}

The limiting factors of both of these substituted vinyl phosphates, the short-lived residual action for control of insects, and their acute oral toxicity, have been offset by the numerous advantages which are:

(1) Complete safety to the consumer, short periods after application.

(2) Wide range of pests controlled.

(3) Rapid control of insects at close to harvest periods

(4) Improving knowledge and experience in the safe handling of organo-phosphorus compounds.

(5) Insects can be controlled in crops, pasture and specific localities with the short residual action being an advantage as there is

(a) Less mortality to beneficial insects (aphid parasites and predators ) migrating to a treated area, as reported by Stern and van den Bosch (1957), and

(b) The effect on honey bees is kept to a minimum as reported by Anderson and Atkins (1958). Bee mortality is a constan problem with the use of long-term residual type insecticides particularly at the time when crops and clover are in full flower.

(6) The use of low water volumes will allow the concentrate spraying machines to be used, thus reducing costs of application Further detailed work is required in this field in New Zealand.

(7) With efficient control initially, the re-infestation periods are reasonably long. Therefore, although specifically useful for close to harvest applications, the materials may be used for general use.

(8) The materials may be of value if a problem of resistance of insects to chemicals does occur.

\section{ACKNOWLEDGEMENTS}

Acknowledgements are made for information supplied by the Agricultural Division of Shell Oil (New Zealand) Ltd., and Shell International Chemical Co. Ltd., London.

\section{REFERENCES}

Anderson, L. D.; Atkins, E. L., Jr. 1958: Effects of pesticides on bees. Calif. Agric., 12 (12).

Butcher, J. W.; Haynes, D. 1958 : Fall control of European pine shoot moth on pine seedlings. Quart. Bull. (Michigan State University), 41 (2)

Casida, J. E.; Gatterdam, P. E.; Getzin, L. W., Jr.; Chapman, R. K 1956: Residual properties of the systemic insecticide 0,0-dimethyl 1-carbomethoxyl-1-propen 2-yl phosphate (phosdrin). Approved for publication by Director, Wisconsin Agric. Exper. Sta.; accepted Jan. 9, 1956, Pesticide Subdivision, Division of Agric. \& Food Chem., A.C.S., Minneapolis, Minn.

Casida J. E.; Gatterdam, P. E.; Knaak, J. B.; Lance, R. D.; Niedermeier, R. P. 1958: Bovine metabolism of organophosphate insecticides. Subacute feeding studies with 0,0-dimethyl 1-carbomethoxy-1-propen-2-yl phosphate. J. Agric. \& Food Chem., 6 (9). 
Chaboussou, F.; Carles, J. P. 1960: Trials for the control of first generation larvae of Cochylis Clysia ambiguella and the first and second generation larvae of Eudemis Polychrosis botrana, in the Bordelais District in 1959. Phytiatrie-Phytopharmacie, 9 (1).

Dormal, S. 1960: Residual effects of insecticides on fruit and vegetables. Span, 3 (2).

Harcourt, D. G.; Cass, L. M. (1959): Control of caterpillars on cabbage in the Ottawa Valley of Ontario and Quebec 1956-7:J. Econ. Entom., 52 (2).

Haynes, D. L.; Guyer, G.; Butcher, J. W. 1958: Use of systemic insecticides for the control of European pine shoot moth infesting red pine. Quart. Bull (Michigan State University), 41 (2).

MacCuaig, R. D.; Yeates, M. 1960: Further studies on the toxicity of insecticides to locusts. A.L.R.U./Porton/Report No. 2/60.

Richardson, A. G. 1958: Phosdrin - a new insecticide. Shell Public Health \& Agric. News, No. 2.

Stern, V. M.; van den Bosch, R. 1957. Field experiments on the effects of insecticides. Hilgardia, 29 (2).

Winfield, J. B. 1960: Phosdrin - a consumer safe insecticide. World Crops, 12 (9).

Wolfenbarger, D.; Hibbs, E. T. 1958: Insecticides and spray schedules for the control of cabbage leaf feeding Lepidoptera. J. Econ. Entom. 51 (4). 